ORIGINAL ARTICLE

\title{
Arsenic-resistant bacteria isolated from agricultural soils of Bangladesh and characterization of arsenate-reducing strains
}

\author{
S.P. Bachate*, L. Cavalca* and V. Andreoni \\ Department of Food Science and Microbiology, University of Milan, Milan, Italy
}

\begin{abstract}
Keywords
agricultural soil of Bangladesh, arsenate reduction, arsenic resistance, ars genes, $16 \mathrm{~S}$ rRNA gene.
\end{abstract}

\section{Correspondence}

Vincenza Andreoni, Department of Food Science and Microbiology, University of Milan, Via Celoria 2, I-20133 Milan, Italy.

E-mail: vincenza.andreoni@unimi.it

*Both authors contributed equally to this work.

2008/1292: received 25 July 2008, revised 28 November 2008 and accepted 30 November 2008

doi:10.1111/j.1365-2672.2009.04188.x

\begin{abstract}
Aims: To analyse the arsenic-resistant bacterial communities of two agricultural soils of Bangladesh, to isolate arsenic-resistant bacteria, to study their potential role in arsenic transformation and to investigate the genetic determinants for arsenic resistance among the isolates.

Methods and Results: Enrichment cultures were performed in a minimal medium in the presence of $\mathrm{As}(\mathrm{III})$ and $\mathrm{As}(\mathrm{V})$ to isolate resistant bacteria. Twenty-one arsenic-resistant bacteria belonging to different genera of Grampositive and Gram-negative bacteria were isolated. The isolates, with the exception of Oceanimonas doudoroffii Dhal $\mathrm{Rw}$, reduced $2 \mathrm{mmol}^{-1} \mathrm{As}(\mathrm{V}) \mathrm{com}$ pletely to As(III) in aerobic conditions. Putative gene fragments for arsenite efflux pumps were amplified in isolates from Dhal soil and a putative arsenate reductase gene fragment was amplified from a Bacillus sp. from Rice soil.

Conclusions: Phylogenetically diverse arsenic-resistant bacteria present in agricultural soils of Bangladesh are capable of reducing arsenate to arsenite under aerobic conditions apparently for detoxification purpose.

Significance and Impact of the Study: This study provides results on identification, levels of arsenic resistance and reduction of arsenate by the bacterial isolates which could play an important role in arsenic cycling in the two arsenic-contaminated soils in Bangladesh.
\end{abstract}

\section{Introduction}

Arsenic is a toxic element released into the environment either by natural phenomena (weathering, volcanic activity) or by anthropogenic activities (Cullen and Reimer 1989). Arsenic mainly occurs in two inorganic forms, arsenate $\mathrm{As}(\mathrm{V})$ and arsenite $\mathrm{As}(\mathrm{III})$ (Neff 1997). The accumulation of arsenic in groundwater is a serious problem in many parts of the world, notably Bangladesh, where arsenic-contaminated groundwater is used for drinking by over 40 million peoples (Smedley and Kinniburgh 2002). Due to the natural abundance of arsenic in the environment, representatives from various bacterial genera have developed different resistance mechanisms for arsenic compounds (Mukhopadhyay et al. 2002; Rosen 2002). While arsenate enters into the microbial cells via transmembrane phosphate transport proteins
(Cervantes et al. 1994), arsenite enters at neutral $\mathrm{pH}$ via aquaglyceroporins (Wysocki et al. 2001). The bacterial resistance with regard to reduction of arsenate or oxidation of arsenite can be divided into two basic categories consisting of either detoxification reactions that confer arsenic resistance, or redox reactions that conserve the energy gained by the reactions for cell growth (Stolz et al. 2002; Silver and Phung 2005). The most widespread resistance mechanisms found in bacteria are ars operons which are either chromosomally or plasmid encoded. The two most common types of these operons contain either five $(\operatorname{ars} R D A B C)$ or three $(\operatorname{ars} R B C)$ genes. The ars operon in Escherichia coli has both plasmid and chromosomal loci (Oremland and Stolz 2003). The arsR gene encodes a transcriptional regulator, ars $B$ encodes a membranebound arsenite carrier that exports arsenite and ars $C$ encodes a reductase that converts arsenate to arsenite 
(Mukhopadhyay and Rosen 2002). In addition, the arsA gene codes for a ATPase subunit (ArsA) which increases the efficiency of arsenite carrier protein, and $\operatorname{ars} D$ codes for an arsenic metalo-chaperone that delivers As(III) to ArsA (Lin et al. 2006). Arsenate respiration and arsenate detoxification are both microbial processes that contribute to arsenic mobilization in soil and groundwater (Oremland and Stolz 2003). Migration of As(III) through soil to groundwater is of great concern, due to its mobility and higher toxicity than As(V). Arsenite has the ability to bind to sulfhydryl groups of proteins and dithiols. Arsenate, on the other hand is a toxic analogue for inorganic phosphorylating activities (Summers and Silver 1978).

Bacterial populations associated with arsenic transformations have been characterized from diverse environments such as in oxic environments (Macur et al. 2004) and in anoxic sediments of lakes and rivers naturally contaminated with arsenic (Cummings et al. 1999; Oremland et al. 2005). The role of dissimilatory arsenatereducing bacteria in arsenic release into groundwater of sedimentary aquifers of Bengal delta has been proved recently (Islam et al. 2004). Similarly, As(V)-reducing bacteria have been also found to mediate the reduction of As $(V)$ under highly aerobic conditions resulting in enhanced mobilization of arsenic from limed mine tailings (Macur et al. 2001).

In Bangladesh, agricultural fields are frequently irrigated with arsenic-contaminated groundwater, particularly the rice paddies (Oryza sativa). A survey on arsenic contamination of paddy field soils in Bangladesh reports the presence of up to $1.7 \mu \mathrm{g} \mathrm{g}^{-1}$ of arsenic in rice grains (Mehrag and Rahman 2003). The ingestion of arseniccontaminated rice and vegetables represents the second most common route of arsenic poisoning with ingestion of contaminated water as first (Chowdhury 2004). The arsenic transformation capabilities of bacteria of these soils can be of great concern because rice plants have been found to take up different arsenic species present in soil, in particular, As(III) at higher rate than As(V), dimethylarsinic acid (DMAA) and monomethylarsonic acid (MMAA) with uptake rates of $147,126,12.7$ and $5.7 \mathrm{nmol} \mathrm{g}^{-1}$ fresh weight per $\mathrm{h}$ for $\mathrm{As}(\mathrm{III}), \mathrm{As}(\mathrm{V})$, MMAA and DMAA, respectively (Abedin et al. 2002).

Our understanding of the aerobic arsenic-resistant bacteria in agricultural soils in Bangladesh and their possible role in arsenic transformation and mobilization is scarce. The aim of present work was (i) to isolate and identify the culturable arsenic-resistant bacterial populations present in arsenic-contaminated paddy rice and lentil field soils of Bangladesh; (ii) to evaluate the arsenic transformations performed by the arsenic-resistant isolates and (iii) to check for the presence of genetic determinants for arsenic resistance among isolates to understand the resistance mechanism involved.

\section{Materials and methods}

\section{Soil characteristics and bacterial counts in soils}

Soil samples $(0-20 \mathrm{~cm})$ were collected from a paddy rice field (Rice soil) and lentil field (Dhal soil) from the Satkhira District (Bangladesh) and the samples were chemically analysed by Martin et al. (2007). The various forms of arsenic content of the soils (total, water-soluble and oxalate-extractable) were determined by following the sequential extraction method of Wenzel et al. (2001).

For microbiological analysis, eight samples of each soil were randomly collected and then mixed together to form two composite samples. Each composite sample was put into plastic bags, transported to the laboratory where they stored moist in the dark at $4^{\circ} \mathrm{C}$ in polyethylene bags for 2 weeks until the analyses.

An initial soil extraction was performed by adding $45 \mathrm{ml}$ of sodium pyrophosphate solution $\left(2 \mathrm{~g} \mathrm{l}^{-1}\right)$ to $5 \mathrm{~g}$ of wet soil. Serial tenfold dilutions of soil samples were prepared in $1: 20$ saline solution (Jensen 1962) for each soil sample (Pochon and Tardieux 1962). Heterotrophic bacteria were determined by plating aliquots $(1 \mathrm{ml})$ of the various dilutions into 1:10 diluted Tryptic Soy Agar (TSA/10) medium in double sets of pour plates. Cycloheximide $\left(0 \cdot 1 \mathrm{~g} \mathrm{l}^{-1}\right)$ was added to the media to inhibit fungal growth. To analyse the arsenic tolerance level of bacterial community in the soil (Kunito et al. 1999), the number of arsenic-tolerant bacteria was determined by plating $1 \mathrm{ml}$ of the various dilutions of soil on TSA/10 medium supplemented with $0.77 \mathrm{mmol} \mathrm{l}^{-1}$ either of sodium arsenate, As(V), or sodium arsenite, As(III) mixed in the medium prior to pouring the plates. The arsenic tolerance of the heterotrophs was expressed as percentage of growth on TSA/10 without arsenic addition. All incubations were carried out at $30^{\circ} \mathrm{C}$ for 10 days. The data were subjected to analysis of variance (ANOVA), and treatment means were compared by Duncan's multiple-range test. All analyses were performed at the $P \leq 0.05$ level.

\section{Enrichment cultures and isolation of arsenic-resistant strains}

To evaluate the arsenic resistance, soil bacteria were grown in the presence of high concentration of arsenic to determine the response to arsenic stress. Soil samples (10 g) were added to flasks containing Tris mineral medium (TMM) at low phosphate content (Mergeay et al. 1985), supplemented with $6 \mathrm{~g} \mathrm{l}^{-1}$ of sodium gluconate (TMMG) and with $20 \mathrm{mmol}^{-1}$ of $\mathrm{As}(\mathrm{V})$ or $5 \mathrm{mmol} \mathrm{l}^{-1}$ 
of As(III). Flasks were incubated under shaking $\left(150 \mathrm{rev} \mathrm{min}^{-1}\right)$ at $30^{\circ} \mathrm{C}$ for 5 days and $10 \mathrm{ml}$ of each of these enrichment cultures were transferred into fresh medium and then incubated under the same conditions. After three subsequent transfers, aliquots of cell suspensions $(15 \mathrm{ml})$ were centrifuged $\left(10^{\circ} \mathrm{C}\right.$ for $20 \mathrm{~min}$ at $13000 \mathrm{~g}$ ) and cell pellets were then subjected to DNA extraction as specified below. To isolate arsenic-resistant bacteria, appropriate dilutions of enrichment cultures were plated on TSA/10 containing $20 \mathrm{mmol}^{-1}$ of As(V) or $5 \mathrm{mmol}^{-1}$ of As(III) and the plates were incubated at $30^{\circ} \mathrm{C}$ for 5 days. After incubation, colonies with different morphologies were selected from the plates. Single colonies were streaked to purity on the same medium. Strains were maintained in glycerol stocks at $-70^{\circ} \mathrm{C}$. Prior to use, the strains were grown to mid-exponential phase in TMMG at $30^{\circ} \mathrm{C}$ with shaking.

\section{Arsenic resistance and transformation of arsenite and arsenate by isolates}

Resistance to $\mathrm{As}(\mathrm{V})$ and $\mathrm{As}(\mathrm{III})$ was determined for each isolate by growing them separately in $20 \mathrm{ml}$ TMMG liquid medium amended with increasing concentrations of $\mathrm{As}(\mathrm{V})$ (from 0 to $650 \mathrm{mmol} \mathrm{l}^{-1}$ ) or As(III) (from 0 to $\left.80 \mathrm{mmol} \mathrm{l}^{-1}\right)$. Two vials for each concentration were inoculated with appropriate cell suspension grown in TMMG without arsenic to obtain cell density of approx. $10^{6} \mathrm{CFU} \mathrm{ml} \mathrm{m}^{-1}$. The growth was evaluated by measuring the $\mathrm{OD}_{600 \mathrm{~nm}}$ after 5 days incubation at $30^{\circ} \mathrm{C}$. Yeast extract $\left(0 \cdot 2 \mathrm{~g} \mathrm{l}^{-1}\right)$ was added to TMMG for isolates Dhal F, Rice D, Dhal P, Dhal Rr and Dhal G as these isolates did not grow without yeast extract after the first transfer. To test the ability of the isolates to reduce $\mathrm{As}(\mathrm{V})$ or oxidize As(III), the strains were grown to mid-exponential phase in TMMG without arsenic and then inoculated into two vials each containing $20 \mathrm{ml}$ of TMMG either with $2 \mathrm{mmol} \mathrm{l}^{-1} \mathrm{As}(\mathrm{V})$ or $1 \mathrm{mmol} \mathrm{l}^{-1} \mathrm{As}(\mathrm{III})$ to obtain an $\mathrm{OD}_{600 \mathrm{~nm}}$ of $0 \cdot 05$. Control flasks without inoculum were incubated to check abiotic transformation of arsenic. At each sampling time, $1 \mathrm{ml}$ of suspension was removed to measure cell growth by $\mathrm{OD}_{600 \mathrm{~nm}}$ and to determine $\mathrm{As}(\mathrm{V})$ and As(III) concentration by spectrophotometric analysis according to method described by Cummings et al. (1999). As (V) concentration was determined by acidifying $100 \mu \mathrm{l}$ sample in $100 \mu \mathrm{l}$ of $\mathrm{HCl}\left(24 \mathrm{mmol} \mathrm{l}^{-1}\right)$. A $100 \mu \mathrm{l}$ of the acidified sample was then added to $900 \mu \mathrm{l}$ of the reaction mixture containing the following: ammonium molybdate $\left(6 \mathrm{~g} \mathrm{l}^{-1}\right)$, ascorbic acid $\left(10 \cdot 8 \mathrm{~g} \mathrm{l}^{-1}\right)$, potassium antimonyl tartrate $\left(0 \cdot 136 \mathrm{~g} \mathrm{l}^{-1}\right)$ and concentrated $\mathrm{H}_{2} \mathrm{SO}_{4}$ $\left(67 \cdot 3 \mathrm{ml} \mathrm{l}^{-1}\right)$. Each component was stored as a separate solution. Samples were heated in a water bath at $78^{\circ} \mathrm{C}$ for $10 \mathrm{~min}$ and placed on ice for $5 \mathrm{~min}$. The absorbance at
$865 \mathrm{~nm}$ was compared to acidified As(V) standards. As(III) concentration was determined by oxidizing a second sample in $100 \mu \mathrm{l}$ of $\mathrm{KIO}_{3}\left(5 \mathrm{mmol} \mathrm{l}^{-1}\right)$ and $\mathrm{HCl}$ $\left(48 \mathrm{mmol} \mathrm{l}^{-1}\right)$ for $10 \mathrm{~min}$ and then reading the $\mathrm{OD}_{865 \mathrm{~nm}}$. Blanks of milli-Q water were used to calibrate the spectrophotometer. New plastic wares were used each time to avoid contamination from excess phosphate from detergents. Standard curves were prepared for concentrations of $0-100 \mu \mathrm{mol}^{-1}$ for both As(V) and As(III). The difference between oxidized and unoxidized samples represented the concentration of As(III). For testing the potential of the strains to respire $\mathrm{As}(\mathrm{V})$, the isolates were aerobically grown in TMMG liquid medium without arsenic and then transferred into vials with butyl rubber stoppers containing TMM with sodium lactate $\left(10 \mathrm{mmol} \mathrm{l}^{-1}\right)$ and $\mathrm{As}(\mathrm{V}) \quad\left(10 \mathrm{mmol} \mathrm{l}^{-1}\right)$ under an atmosphere of $\mathrm{N}_{2} / \mathrm{CO}_{2} / \mathrm{H}_{2}(85: 5: 10)$. The vials were incubated in static conditions at $30^{\circ} \mathrm{C}$ for 7 days. After incubation, the samples were analysed for growth by $\mathrm{OD}_{600 \mathrm{~nm}}$ and arsenic concentration as described above.

\section{DNA extraction methods}

DNA from enrichment cultures was extracted by a conventional not organic solvent method (G-NOME BIO 101, QBiogene, Illkirch Cedex, France). Cell suspension solution $(1.85 \mathrm{ml})$ was added to the pellet $(50 \mathrm{mg}$ of fresh weight) obtained from freshly grown liquid culture and $50 \mu \mathrm{l}$ of RNase was added to the sample. Then the sample was incubated at $55^{\circ} \mathrm{C}$ for $2 \mathrm{~h}$ in the presence of $100 \mu \mathrm{l}$ cell lysis solution and $25 \mu \mathrm{l}$ of Proteinase mix. Samples were precipitated in the presence of $8 \mathrm{ml} 100 \%$ ethanol and the DNA pellet was resuspended in $200 \mu \mathrm{l}$ TE $\left(10 \mathrm{mmol}^{-1}\right.$ Tris $\mathrm{HCl} \mathrm{pH} 8.0$ and $1 \mathrm{mmol}^{-1} \mathrm{Na}_{2}$ EDTA $\mathrm{pH} 8 \cdot 0)$. DNA from pure strains was extracted from TMMG overnight-grown liquid cultures by Proteinase $\mathrm{K}$ digestion (1 mg ml${ }^{-1}$ ) according to Cavalca et al. (2004). The DNA-containing supernatant was withdrawn and put in sterile microtubes.

\section{Identification of isolates and 16S rRNA gene analysis}

The complete 16S rRNA gene was amplified from $20 \mathrm{ng}$ DNA using eubacterial primers P27f and P1495r (Weisburg et al. 1991). PCR reactions were performed in a final volume of $50 \mu \mathrm{l}$ containing $10 \mathrm{ng}$ of DNA, 1.5 U of Taq polymerase, $0 \cdot 2 \mu \mathrm{mol} \mathrm{l^{-1 }}$ of each primer, $0 \cdot 2 \mathrm{mmol} \mathrm{l}^{-1}$ of dNTPs, $1.75 \mathrm{mmol} \mathrm{l}^{-1} \mathrm{MgCl}_{2}$, and $1 \times$ PCR buffer. DNA amplification conditions were, initial denaturation at $95^{\circ} \mathrm{C}$ for $5 \mathrm{~min}, 35$ cycles of $95^{\circ} \mathrm{C}$ for $1 \mathrm{~min}, 55^{\circ} \mathrm{C}$ for $40 \mathrm{~s}, 72^{\circ} \mathrm{C}$ for $1 \mathrm{~min} 40 \mathrm{~s}$ and then a final extension step at $72^{\circ} \mathrm{C}$ for $10 \mathrm{~min}$. Isolates were grouped on the basis of amplified ribosomal DNA restriction analysis (ARDRA) 
by using restriction enzyme HhaI. One representative isolate of each group was selected and its 16S rRNA gene was sequenced.

Amplification of hypervariable region V3 internal to the 16S rRNA gene amplified from enrichment cultures was performed using a nested PCR approach: the $16 \mathrm{~S}$ rDNA PCR products were 100-fold diluted and then used as template for a second amplification step of the V3 hypervariable region with primer pair P341f and P534r. PCR reactions (final volume $50 \mu \mathrm{l}$ ) contained the following: $10 \mathrm{ng}$ of $16 \mathrm{~S} \mathrm{rDNA}, 1 \mathrm{U}$ of Taq polymerase, $0 \cdot 2 \mu \mathrm{mol} \mathrm{l}^{-1}$ of each primer, $0.2 \mathrm{mmol} \mathrm{l}^{-1}$ of dNTPs, $1.75 \mathrm{mmol} \mathrm{l}^{-1} \mathrm{MgCl}_{2}$ and $1 \times$ PCR buffer. The samples were first denatured for $3 \mathrm{~min}$ at $94^{\circ} \mathrm{C}$ and then subjected to 19 cycles consisting of $1 \mathrm{~min} 20 \mathrm{~s}$ at $94^{\circ} \mathrm{C}, 1 \mathrm{~min} 30 \mathrm{~s}$ at $65^{\circ} \mathrm{C}$ and $1 \mathrm{~min} 10 \mathrm{~s}$ at $72^{\circ} \mathrm{C}$; the annealing temperature was decreased by $1^{\circ} \mathrm{C}$ every second cycle until touchdown at $55^{\circ} \mathrm{C}$, at which temperature seven additional cycles were carried out. The last step included an extension of $5 \mathrm{~min}$ at $72^{\circ} \mathrm{C}$.

\section{Cloning}

Clone libraries of hypervariable V3 16S rRNA regions of the DNA from As(V) $\left(20 \mathrm{mmol} \mathrm{l}^{-1}\right)$ and As(III) $\left(5 \mathrm{mmol} \mathrm{l}^{-1}\right)$ enrichment cultures of both soils were prepared in order to describe species composition. V3 fragments were amplified as described above and PCR products were purified by QIAquick PCR purification columns (Qiagen, Germany) and ligated into $\mathrm{pCR}^{\circledR} \mathrm{II}-\mathrm{TOPO}$ TA cloning vector (Invitrogen). After chemical transformation into library efficiency $\mathrm{DH} 5 \alpha^{\mathrm{TM}}$ competent cells (Invitrogen), 50 white colonies from each experiment were screened for the presence of the correct size insert by colony PCR using vector-specific primers (M13 forward and reverse). Sequence analysis was performed on representative clones showing different HhaI (GE Healthcare, Sweden) restriction fragment length polymorphisms. Analogously, PCR products of eubacterial 16S rRNA and arsenic resistance gene fragments amplified from isolated strains were cloned into $\mathrm{pCR}^{\circledR} \mathrm{II}-\mathrm{TOPO}$ TA cloning vector. All the selected clones were directly sequenced by using M13 forward and reverse primers. Sequence reactions were performed by using the Taq Dye-Deoxy Terminator Cycle Sequencing kit (Applied Biosystems, USA) and analysed by automatic DNA sequencer 310A apparatus (Applied Biosystems).

\section{Primer design for arsenic resistance genes and PCR conditions}

All the primers used for analysis of arsenic resistance genes are reported in Table 1. Four different primer sets were used to amplify genes for arsenate reductase $(\operatorname{ars} C)$ and arsenite transporter (arsB). A total of 50 bacterial gene sequences involved in arsenic resistance were obtained from GenBank. Preliminary phylogenetic analyses classified the gene sequences into categories corresponding to the different $\operatorname{ars} C$ genes of bacterial phylogenetic groups. Taking into account these sequence variations and the presence of different bacterial genera among Rice and Dhal soil isolates, in the present work degenerate primer pair P52f and P323r was designed on the basis of the consensus sequence of ars $C$ genes of $16 \mathrm{~S}$ rRNA-Group 1 of Bacillus species (i.e. B. cereus ATTC 10987 acc. num. AE017194, B. thuringiensis 97-27 acc. num. AE017355 and B. anthracis Ames Ancestor acc. num. AE017334). Primer sets darsB1FdarsB1R, dacr1F-dacr1R and dacr5F-dacr4R were described by Achour et al. (2007) were used to amplify arsenite transporter ( $\operatorname{ars} B$ and $A C R 3 p$ ) genes.

PCR reactions for $a r s B$ and ars $C$ gene fragments selected in this work were performed in a final volume of $25 \mu \mathrm{l}$ containing: $10 \mathrm{ng}$ DNA, $0 \cdot 2 \mathrm{mmol}^{-1}$ of dNTPs, $1.75 \mathrm{mmol} \mathrm{l}^{-1} \mathrm{MgCl}_{2}, 0.4 \mu \mathrm{mol} \mathrm{l}^{-1}$ of each primer, $2 \mathrm{U}$ of Taq polymerase and $1 \times$ PCR buffer. DNA amplification conditions for P52f-P323r were: initial denaturation at $94^{\circ} \mathrm{C}$ for $5 \mathrm{~min}, 40$ cycles of $94^{\circ} \mathrm{C}$ for $45 \mathrm{~s}, 55^{\circ} \mathrm{C}$ for $45 \mathrm{~s}, 72^{\circ} \mathrm{C}$ for $30 \mathrm{~s}$ and then a final extension step at $72^{\circ} \mathrm{C}$ for $7 \mathrm{~min}$. DNA amplification conditions for primer sets darsB1F-darsB1R, dacr1F-dacr1R and dacr5F/dacr4R were as described by Achour et al. (2007). PCR products were cloned and sequenced as described above.

\begin{tabular}{llll}
\hline $\begin{array}{l}\text { Primer } \\
\text { name }\end{array}$ & $\begin{array}{l}\text { Primer sequence } \\
\left(5^{\prime}-3^{\prime}\right)\end{array}$ & $\begin{array}{l}\text { PCR product } \\
(\mathrm{bp})\end{array}$ & Reference \\
\hline darsB1F & TGTGGAACATCGTCTGGAAYGCNAC & & \\
darsB1R & CAGGCCGTACACCACCAGRTACATNCC & arsB (750) & Achour et al. (2007) \\
dacr1F & GCCATCGGCCTGATCGTNATGATGTAYCC & & \\
dacr1R & CGGCGATGGCCAGCTCYAAYTTYTT & ACR 3(1) (750) & Achour et al. (2007) \\
dacr5F & TGATCTGGGTCATGATCTTCCCVATGMTGVT & ACR 3(2) (750) & Achour et al. (2007) \\
dacr4R & CGGCCACGGCCAGYTCRAARAARTT & & \\
P52F & AGCCAAATGGCAGAAGC & arsC (275) & This study \\
P323R & GCTGGRTCRTCAAATCCCCA & & \\
\hline
\end{tabular}

Table 1 Primers used in this study for the amplification of arsenic detoxification-related genes: arsenite transporters (arsB, $A C R 3 p$ ) and arsenate reductase (ars $C$ ) 


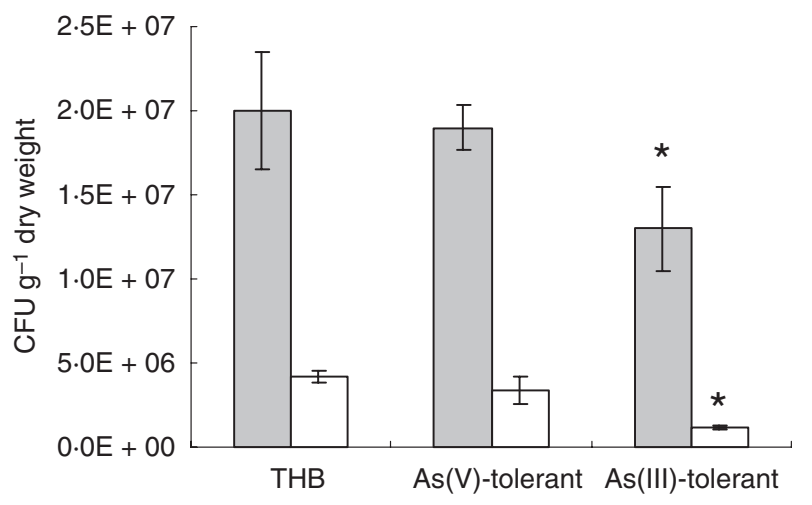

Figure 1 Counts of heterotrophs, As(V)-tolerant $\left(0.77 \mathrm{mmol}^{-1}\right)$ and As(III)-tolerant $\left(0.77 \mathrm{mmol}^{-1}\right)$ bacteria expressed as CFU g ${ }^{-1}$ soil dry weight in Rice and Dhal soils (gray $=$ Rice, white $=$ Dhal). THB, total heterotrophic bacteria grown on TSA/10. Data are expressed as mean \pm standard deviation of four replicates. ${ }^{*}$, statistically significant values when compared with the THB and given in text $\left(\chi^{2}, P \leq 0.05\right)$.

All reagents were from Invitrogen (UK), unless otherwise stated. PCR reactions were performed on T-Gradient Biometra thermocycler (Germany). The PCR products were checked on $2 \%$ agarose gel and visualized by ethidium bromide staining by using the Gel Doc image analyzer system (Bio-Rad, USA).

\section{Sequence analysis and phylogenetic tree construction}

$16 \mathrm{~S}$ rRNA (600-800 bp) and ars gene sequences were searched for homology by using the NCBI-BLAst2 Nucleotide and Protein Database Query program (http:// www.ebi.ac.uk/blastall/index.html). Phylogenetic analysis of ArsC, ArsB and ACR 3p deduced amino acid sequences were performed using MEGA version 3.1 software (Kumar et al. 2004). Phylogenetic trees were constructed using the neighbour-joining distance method based on p-distance. A total of 500 bootstrap replications were calculated. Sequences obtained in the present work were deposited in the EBI database. The accession numbers from FM163604 to FM163615 are for 16S rRNA genes and accession numbers AM983535, AM990469, AM990470 and AM990471 are for ars genes.

\section{Results}

\section{Arsenic content and bacterial counts in soils}

The two study soils showed similar $\mathrm{pH}$ values, between $8 \cdot 4$ (Rice soil) and 8.6 (Dhal soil). Both soils were calcareous and had low organic carbon content which was double in the Rice soil $(0 \cdot 97 \%)$ than in the Dhal soil $(0 \cdot 44 \%)$. The amount of total arsenic $\left(10 \cdot 1 \pm 0 \cdot 42\right.$ vs $7 \cdot 8 \pm 0.81 \mathrm{mg} \mathrm{kg}^{-1}$ dry weight) was similar in the two study soils (Martin et al.
2007). The soils did differ in the labile forms, in particular, Rice soil contained approximately double the amount of water-soluble arsenic and oxalate-extractable arsenic than Dhal soil $\left(6 \cdot 2 \pm 0.24 \mu \mathrm{g} \mathrm{kg}^{-1}\right.$ vs $3.5 \pm 0.14 \mu \mathrm{g} \mathrm{kg}^{-1}$ and $2 \cdot 51 \pm 0.43 \mu \mathrm{g} \mathrm{kg}^{-1}$ vs $1 \cdot 13 \pm 0.3 \mu \mathrm{g} \mathrm{kg}^{-1}$, respectively).

The abundance of heterotrophs and arsenic-tolerant bacteria in Rice and Dhal soils are shown in Fig. 1. The counts of total heterotrophs and of $\mathrm{As}(\mathrm{V})$ - and As(III)tolerant bacteria were high in the Rice soil than in the Dhal soil, probably due to higher organic carbon content in the Rice soil (Monod 1950). No significant difference in number of heterotrophs and $\mathrm{As}(\mathrm{V})$-tolerant bacteria was observed in the two soils at the As(V) level examined $\left(0.77 \mathrm{mmol} \mathrm{l}^{-1}\right)$ probably for the low toxic effect of the $\mathrm{As}(\mathrm{V})$ amount added to TSA/10 medium and the low

Table 2 Identification of culturable isolates from Rice and Dhal soils and their $\mathrm{As}(\mathrm{V}) / \mathrm{As}(\mathrm{III})$ resistance levels

\begin{tabular}{|c|c|c|c|c|}
\hline \multirow[b]{2}{*}{ Isolate } & \multirow{2}{*}{$\begin{array}{l}\text { Closest GenBank } \\
\text { match (\% identity)* }\end{array}$} & \multirow{2}{*}{$\begin{array}{l}\text { Enrichment } \\
\text { culture isolated } \\
\text { from }\end{array}$} & \multicolumn{2}{|c|}{$\begin{array}{l}\text { Arsenic } \\
\text { resistance } \dagger \\
\left(\mathrm{mmol} \mathrm{I}^{-1}\right)\end{array}$} \\
\hline & & & $A s(V)$ & As(III) \\
\hline Dhal A & Arthrobacter sp. (99) & $\operatorname{As}(\mathrm{V})$ & $>650$ & 70 \\
\hline Dhal L & Alcaligenes sp. (99) & $\mathrm{As}(\mathrm{V})$ & 350 & 70 \\
\hline Dhal N & Alcaligenes sp. (99) & $\operatorname{As}(I I I)$ & 350 & 70 \\
\hline Dhal Rw & $\begin{array}{l}\text { Oceanimonas } \\
\text { doudoroffii (97) }\end{array}$ & $\operatorname{As}(\mathrm{V})$ & $>650$ & 1 \\
\hline Dhal D & Arthrobacter sp. (98) & $\operatorname{As}(\mathrm{V})$ & 300 & 20 \\
\hline Dhal E & Arthrobacter sp. (98) & As(III) & 300 & 20 \\
\hline Dhal G & $\begin{array}{l}\text { Arsenicicoccus } \\
\text { bolidensis (100) }\end{array}$ & $\operatorname{As}(I I I)$ & 250 & 20 \\
\hline Dhal S & $\begin{array}{l}\text { Arsenicicoccus } \\
\text { bolidensis (100) }\end{array}$ & $\operatorname{As}(\mathrm{V})$ & 250 & 20 \\
\hline Dhal B & $\begin{array}{l}\text { Microbacterium } \\
\text { hydrocarbonoxydans (100) }\end{array}$ & As(III) & 150 & 30 \\
\hline Dhal C & $\begin{array}{l}\text { Microbacterium } \\
\text { hydrocarbonoxydans (100) }\end{array}$ & $\operatorname{As}(I I I)$ & 150 & 30 \\
\hline Dhal P & Kocuria erythromyxa (100) & $\operatorname{As}(I I I)$ & 100 & 5 \\
\hline Dhal Q & Staphylococcus succinus (100) & $\operatorname{As}(I I I)$ & 100 & 5 \\
\hline Dhal F & Variovorax paradoxus (99) & $\operatorname{As}(I I I)$ & 30 & 15 \\
\hline Dhal $\mathrm{Rr}$ & Arthrobacter agilis (100) & $\mathrm{As}(\mathrm{V})$ & 100 & 5 \\
\hline Rice A & Bacillus megaterium (100) & $\mathrm{As}(I I I)$ & 200 & 30 \\
\hline Rice B & Bacillus megaterium (100) & $\operatorname{As}(I I I)$ & 200 & 30 \\
\hline Rice $\mathrm{H}$ & Bacillus megaterium (100) & $\mathrm{As}(\mathrm{V})$ & 200 & 30 \\
\hline Rice C & Bacillus sp. DT10 (99) & $\mathrm{As}(\mathrm{V})$ & 200 & 20 \\
\hline Rice D & $\begin{array}{l}\text { Microbacterium } \\
\text { hydrocarbonoxydans (100) }\end{array}$ & $\operatorname{As}(I I I)$ & 150 & 30 \\
\hline Rice $\mathrm{E}$ & $\begin{array}{l}\text { Microbacterium } \\
\text { hydrocarbonoxydans (100) }\end{array}$ & $\operatorname{As}(I I I)$ & 150 & 30 \\
\hline Rice $F$ & $\begin{array}{l}\text { Microbacterium } \\
\text { hydrocarbonoxydans (100) }\end{array}$ & $\mathrm{As}(\mathrm{V})$ & 150 & 30 \\
\hline
\end{tabular}

*The $16 \mathrm{~S}$ rRNA identity of the isolates was determined by analysing 600-800 bp.

$\dagger$ The resistance to $\mathrm{As}(\mathrm{V})$ and $\mathrm{As}(\mathrm{III})$ was evaluated by a tenfold increase in $\mathrm{OD}_{600 \mathrm{~nm}}$ of the inoculum. 
ratio of arsenic to phosphate, i.e. $0 \cdot 77-1 \cdot 6 \mathrm{mmol} \mathrm{l}^{-1}$ (Cervantes and Chavez 1992). Both soils contained high percentage of $\mathrm{As}(\mathrm{III})$-tolerant bacteria and their percentage was higher in Rice soil (65\%) than in Dhal soil (29\%).

\section{Identification of isolates and their arsenic resistance pattern}

A total of 21 arsenic-resistant bacteria were isolated from the enrichment cultures, 14 isolates were from Dhal soil and 7 from Rice soil. The isolates were identified by partially (600-800 bp) sequencing the $16 \mathrm{~S}$ rRNA gene. The isolates from Rice soil belonged to the genera Bacillus and Microbacterium; in contrast, those from the less polluted Dhal soil belonged to eight different genera as Arthrobacter, Bacillus, Alcaligenes, Kocuria, Staphylococcus, Microbacterium, Variovorax and Oceanimonas (Table 2).

Resistance to $\mathrm{As}(\mathrm{V})$ and $\mathrm{As}(\mathrm{III})$ of the isolates was determined by measuring the $\mathrm{OD}_{600 \mathrm{~nm}}$ after 5 days growth in TMMG broth amended with various concentrations of $\mathrm{As}(\mathrm{V})$ and $\mathrm{As}(\mathrm{III})$. The isolates varied in their arsenic resistance pattern showing from moderate to high resistance to $\mathrm{As}(\mathrm{V})$ and $\mathrm{As}(\mathrm{III})$ (Table 2). Isolates Arthrobacter sp. Dhal A, Alcaligenes sp. Dhal L and Dhal $\mathrm{N}$ exhibited the highest resistance to arsenic resisting up to $70 \mathrm{mmol} \mathrm{l}^{-1}$ of As(III) and up to $350 \mathrm{mmol} \mathrm{l}^{-1}$ of As $(\mathrm{V})$. Other isolates of Arthrobacter genus (Dhal $\mathrm{Rr}$, Dhal D and Dhal E) exhibited a different and lower resistance pattern when compared with isolate Dhal A. An isolate, Oceanimonas doudoroffii Dhal Rw, was highly resistant to $\mathrm{As}(\mathrm{V})\left(>650 \mathrm{mmol} \mathrm{l}^{-1}\right.$ ) but scarcely grew in the presence of $1 \mathrm{mmol} \mathrm{l}^{-1} \mathrm{As}(\mathrm{III})$. The isolates (Dhal B, Dhal C, Rice D, Rice E, Rice F and Rice G), all represented by Microbacterium genus, although derived from the two soils, had the same arsenic resistance pattern and all resisted up to $150 \mathrm{mmol} \mathrm{l}^{-1} \mathrm{As}(\mathrm{V})$ and up to $30 \mathrm{mmol} \mathrm{l}^{-1} \mathrm{As}$ (III). A group of Gram-positive bacteria which included Dhal G, Dhal S, Dhal P, Dhal Q, Rice A, Rice B, Rice $\mathrm{H}$ and Rice $\mathrm{C}$ resisted from 5 to $30 \mathrm{mmol}^{-1}$ As(III) and from 100 to $250 \mathrm{mmol} \mathrm{l}^{-1} \mathrm{As}(\mathrm{V})$. Finally, Variovorax paradoxus Dhal F, although showing high resistance to As(III), was the bacterium with the lowest resistance to $\mathrm{As}(\mathrm{V})$.

\section{Clone libraries of enrichment cultures}

The V3 regions amplified from the cultures enriched in presence of $20 \mathrm{mmol} \mathrm{l}^{-1} \mathrm{As}(\mathrm{V})$ and $5 \mathrm{mmol} \mathrm{l}^{-1} \mathrm{As}$ (III) of both soils were cloned and sequenced in order to describe the species highly resistant to stress imposed. The comparison of the cloned sequences with GenBank database revealed the presence of different populations (Table 3). The majority of cloned sequences obtained from the Dhal soil culture enriched on $20 \mathrm{mmol} \mathrm{l}^{-1} \mathrm{As}(\mathrm{V})$ belonged to Diaphorobacter sp. (58\% of total clone library) and Arthrobacter sp. (39\% of total clone library), while Methylobacterium sp. was present in lower percentage, which was $3 \%$ of total clone library. Cloned sequences obtained from $5 \mathrm{mmol} \mathrm{l}^{-1} \mathrm{As}$ (III) enrichment culture of Dhal soil belonged to Bacillus litoralis $(88.8 \%$ of total clone library), Paenibacillus thiaminolyticus, Strenotrophomonas

Table 3 Identification of cloned 16S rRNA sequences obtained from Rice and Dhal soil enrichment cultures

\begin{tabular}{|c|c|c|c|c|}
\hline OUT* & Closest GenBank match & Accession No. & Identity (\%) & $\begin{array}{l}\text { Abundance (\% of } \\
\text { total clone library) }\end{array}$ \\
\hline \multicolumn{5}{|c|}{ Dhal soil enrichment culture in $5 \mathrm{mmol} \mathrm{I}^{-1} \mathrm{As}(\mathrm{III})$} \\
\hline Clone D1As(III) & Stenotrophomonas maltophilia & DQ466574 & 100 & $2 \cdot 22$ \\
\hline Clone D2As(III) & Paenibacillus thiaminolyticus & AJ320490 & 100 & $4 \cdot 44$ \\
\hline Clone D3As(III) & Arthrobacter oxydans & X83408 & 100 & $4 \cdot 44$ \\
\hline Clone D4As(III) & Bacillus litoralis & AY608605 & 100 & $88 \cdot 8$ \\
\hline \multicolumn{5}{|c|}{ Dhal soil enrichment culture in $20 \mathrm{mmol} \mathrm{I-1} \mathrm{As}(\mathrm{V})$} \\
\hline Clone D1As(V) & Diaphorobacter sp. & DQ987613 & 97 & 58 \\
\hline Clone D2As(V) & Arthrobacter eutrophus & M32021 & 100 & 39 \\
\hline Clone D3As(V) & Methylobacterium sp. AC72a & AY776209 & 100 & 3 \\
\hline \multicolumn{5}{|c|}{ Rice soil enrichment culture in $5 \mathrm{mmol} \mathrm{I}^{-1} \mathrm{As}(\mathrm{III})$} \\
\hline Clone R1As(III) & Stenotrophomonas maltophilia & $\times 95924$ & 100 & $3 \cdot 77$ \\
\hline Clone R2As(III) & Paenibacillus thiaminolyticus & Y16129 & 99 & $67 \cdot 9$ \\
\hline Clone R3As(III) & Ancylobacter sp. OL1 & DQ986318 & $98-100$ & $28 \cdot 3$ \\
\hline \multicolumn{5}{|c|}{ Rice soil enrichment culture in $20 \mathrm{mmol} \mathrm{I}^{-1} \mathrm{As}(\mathrm{V})$} \\
\hline Clone R1As(V) & Bacillus benzovorans & Y14693 & $99-100$ & 96 \\
\hline Clone R2As(V) & Pseudoxanthomonas mexicana & AY124375 & 100 & 2 \\
\hline Clone R3As(V) & Bacillus sp. MDSO1 & EU236670 & 100 & 2 \\
\hline
\end{tabular}

*OUT, operational taxonomic unit. 

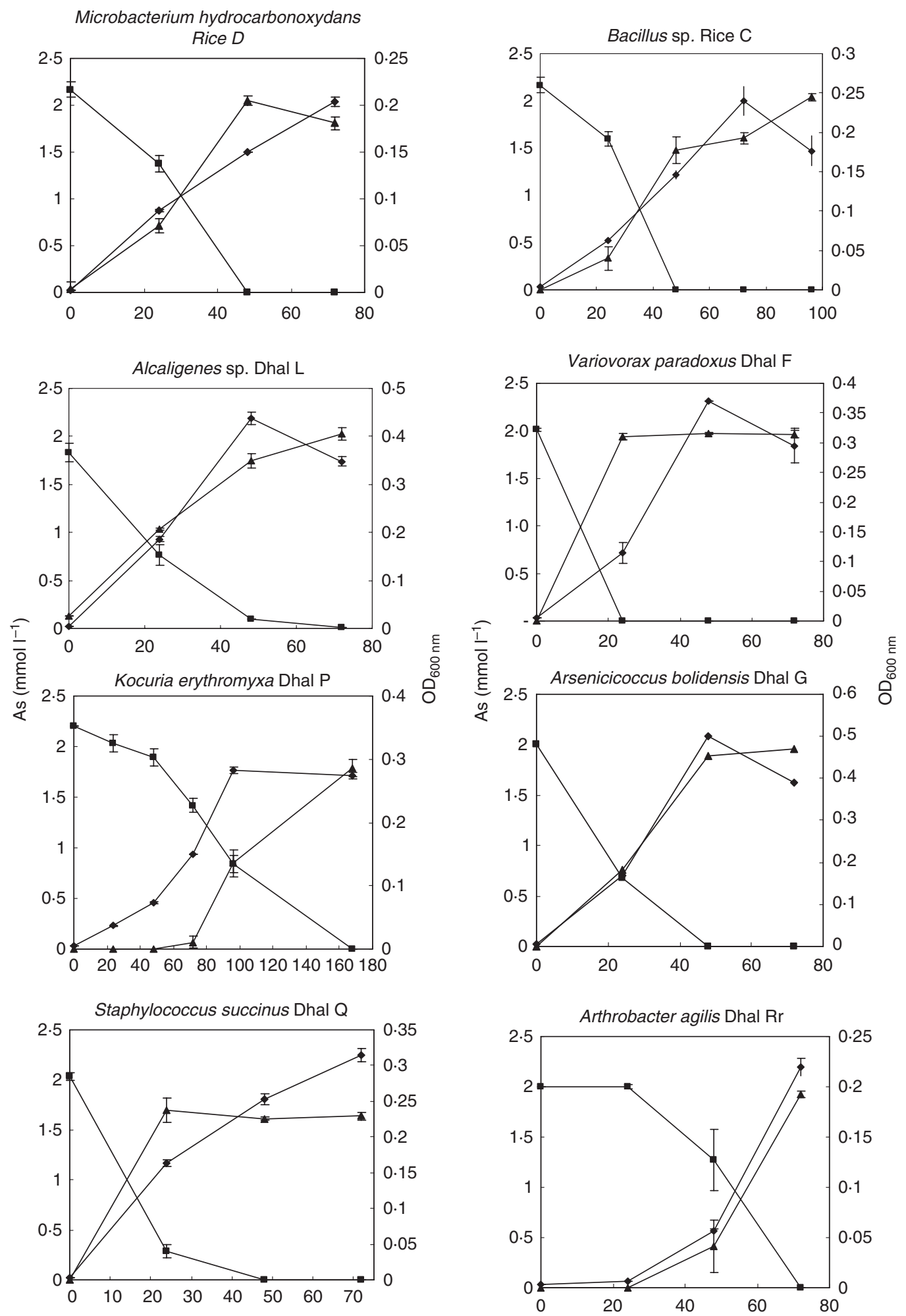

Time (h)

Figure 2 Bacterial growth $\left(\mathrm{OD}_{600 \mathrm{~nm}}\right)(\bullet)$ and corresponding reduction of $\mathrm{As}[\mathrm{V}]$

to $\operatorname{As}[I I I]$ ( $\mathbf{\Lambda}$ ) by eight isolates from Dhal and Rice soil. The OD values reported are 1: 10 dilution of original sample. Data are represented as means \pm standard error, $n=4$. 
(a)

100 Dhal L (AM983535)
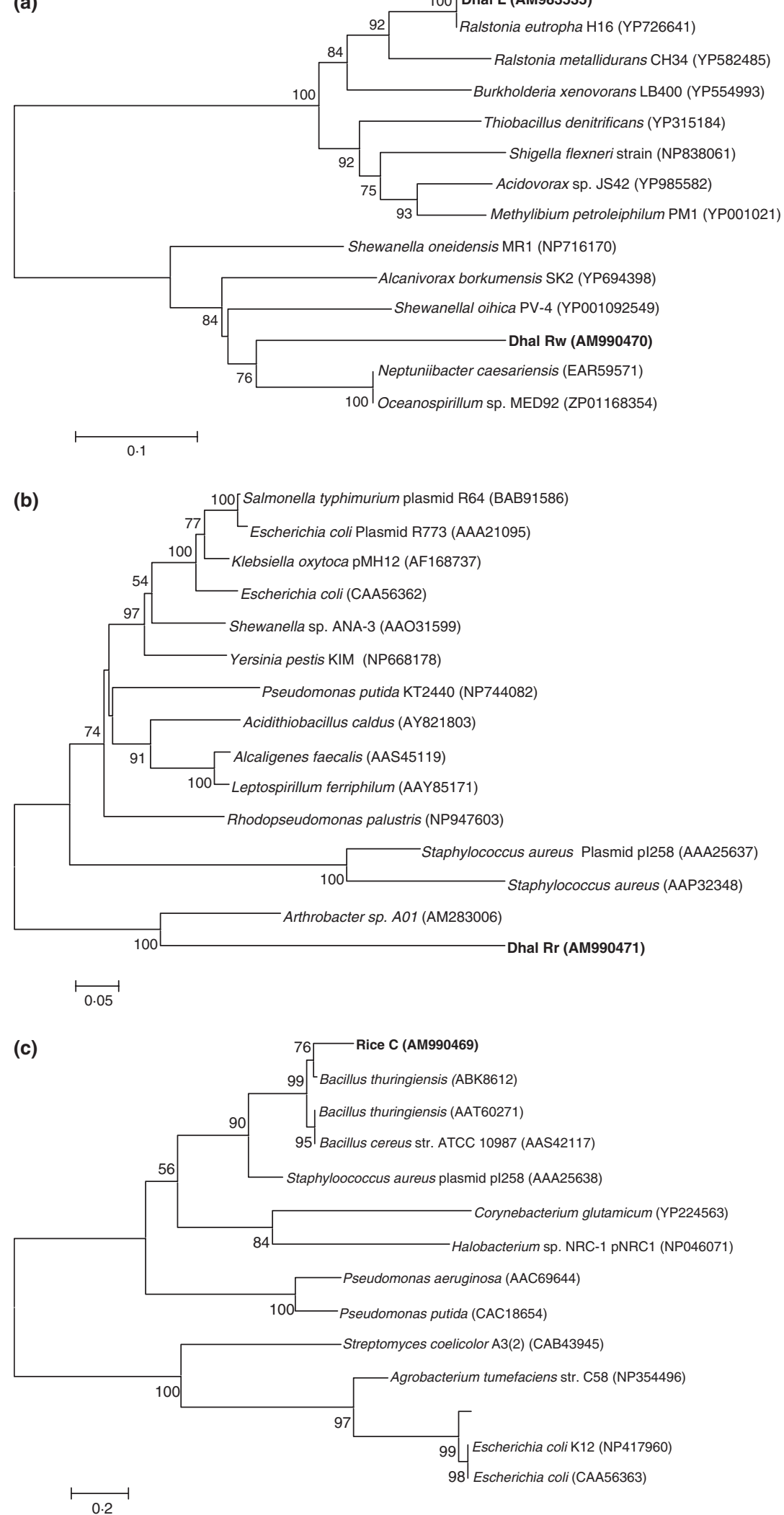
maltophilia and Arthrobacter oxydans. The $98 \%$ of cloned sequences obtained from $20 \mathrm{mmol} \mathrm{l}^{-1} \mathrm{As}(\mathrm{V})$ Rice soil enrichment culture belonged to genus Bacillus and only 2\% belonged to Pseudoxanthomonas mexicana. The $5 \mathrm{mmol} \mathrm{l}^{-1}$ As(III) enrichment culture of Rice soil showed presence of cloned sequences corresponding to $P$. thiaminolyticus $(67 \cdot 9 \%$ of total clone library), to Ancylobacter sp. (28.3\% of total clone library) and to S. maltophilia (3.77\% of total clone library).

\section{Arsenic transformation by isolates}

To verify the presence of detoxification mechanisms in arsenic-resistant bacteria, As(V) reduction and As(III) oxidation profiles were studied for 21 isolates. With the exception of $O$. doudoroffii Dhal Rw that did not reduce As $(\mathrm{V}), 20$ isolates tested reduced $2 \mathrm{mmol} \mathrm{l}^{-1} \mathrm{As}(\mathrm{V})$ completely to As(III) under aerobic conditions. As an example of the reducing capability of the isolates, we reported the growth and $\mathrm{As}(\mathrm{V})$ reduction profiles of one isolate representing each genus (Fig. 2). The time required for the complete reduction varied in the isolates. Isolates Rice C, Dhal L and Dhal F reduced it completely in 24-48 h, while Dhal $\mathrm{P}$ and Dhal $\mathrm{Rr}$ required longer time for complete reduction of $\mathrm{As}(\mathrm{V})$. Complete reduction of $\mathrm{As}(\mathrm{V})$ occurred when strains attained maximum cell density. $\mathrm{As}(\mathrm{V})$ reduction did not occur in controls without cells indicating that $\mathrm{As}(\mathrm{V})$ reduction was a microbial process.

None of these strains reduced $\mathrm{As}(\mathrm{V})$ in the absence of oxygen and none isolates oxidized As(III) under aerobic conditions.

\section{Analysis of ars genes in isolates}

Arsenic resistance genes were searched in order to investigate the presence of arsenic resistance determinants among the isolates. A $275 \mathrm{bp}$ fragment of putative ars $C$ gene from Bacillus sp. Rice C (primer set P52F/P323R), a 850 bp fragment of putative arsB gene from Arthrobacter agilis Dhal $\mathrm{Rr}$ (primer set darsB1F/darsB1R) and a $750 \mathrm{bp}$ putative $A C R 3(2)$ gene fragment (primer set dacr5F/dacr4R) from O. doudoroffii Dhal Rw and Alcaligenes sp. Dhal L were successfully amplified. Phylogenetic trees were constructed to study the phylogenetic relationship of the translated amino acid sequences of $A C R 3(2)$, $\operatorname{ars} C$ and $a r s B$ genes with previously known sequences (Fig. 3). Phylogenetic analysis of inferred amino acid sequence of $\operatorname{Acr} 3(2)$ protein of isolates Alcaligenes sp.
Dhal L and O. doudoroffii Dhal Rw placed them in two distinct clusters formed by putative Acr3(2) proteins of $\beta$-proteobacteria and $\gamma$-proteobacteria respectively, except for Shigella flexneri which was placed together with $\beta$-proteobacteria. ArsC amino acid sequence of Bacillus sp. Rice C was placed in cluster formed by Staphylococcus Trx ArsC family together with putative arsC proteins of other Bacillus species. The length of ars $B$ gene fragment obtained from Arthrobacter sp. Dhal $\mathrm{Rr}$ was $850 \mathrm{bp}$ although expected size was $750 \mathrm{bp}$ and its inferred amino acid sequence was related only with ArsB sequence of Arthrobacter sp. A01 characterized by Achour et al. (2007) but not with other known ArsB sequences.

\section{Discussion}

The two agricultural soils investigated in this study showed a moderate arsenic concentration (Huq et al. 2003) and the total arsenic content of the Rice soil was close to the levels usually reported in paddy rice fields in Bangladesh (Alam and Sattar 2000). The higher level of labile arsenic forms in the Rice soil than in the Dhal soil can be a consequence of the higher water requirement of rice crop. The heterotrophs were inhibited by $0.77 \mathrm{mmol} \mathrm{l}^{-1}$ of As(III) but not by As(V). The higher number of As(III)-tolerant bacteria in Rice than in Dhal soil can be ascribed to the higher content of water-soluble and oxalate-extractable arsenic in the former. Moreover, under reducing conditions that can occur in flooded soils, like the rice fields, As(III) can be the predominant arsenic species and generally less retained by soil colloids (Sadiq 1997; Bissen and Frimmel 2003). In lentil field soil, oxidizing conditions are maintained for many months in a monsoon climate and, with $\mathrm{As}(\mathrm{V})$ being the dominant species, a stronger retention of arsenic by soil colloids could be expected. These results can suggest that labile arsenic forms rather than the total arsenic content can be considered in evaluating the arsenic tolerance of bacterial communities.

Diversity in the composition of enrichment cultures was observed by comparing the arsenic-resistant isolates and clone libraries. The isolates from Rice soil belonged to two genera, while the cloned sequences corresponded to five genera. Bacillus species were the dominant clones in the As(V)-enriched culture and were effectively isolated. In As(III)-enriched culture from Rice soil Paenibacillus and Ancylobacter were the dominant species but these species were not isolated. The isolated strains from

Figure 3 Phylogenetic tree of inferred amino acid sequences of arsenic resistance genes (a) $A C R 3(2)$ genes of isolates Dhal $L$ and Dhal Rw, (b) $\operatorname{ars} B$ gene of Dhal $\mathrm{Rr}$ and (c) arsC gene of Rice C. Sequences obtained in this study are in bold type. Numbers above nodes represent bootstrap confidence values obtained with 500 resamplings; values below 50 are not shown. The GenBank accession numbers for the corresponding arsenic resistance gene sequences are given in parentheses. Scale bar indicates substitutions per site. 
Dhal soil belonged to nine genera, while the cloned sequences corresponded to six genera. Among these, Arthrobacter was isolated but not the Strenotrophomonas, Paenibacillus, Diaphorobacter and Methylobacter. This discrepancy could be due to the exposure of enrichment cultures to toxic levels of arsenic which could have hampered the growth of more sensitive populations. The enrichment conditions, however, do not reproduce real conditions of an environmental sample and select the micro-organisms growing faster and adapting better to the growth conditions imposed. However, all of cloned sequences belonged to species reported to have arsenic resistance (Jackson et al. 2005a,b; Achour et al. 2007).

Twenty-one heterotrophic aerobic arsenic-resistant bacteria representing different genera in the Gram-positive and Proteobacteria groups were isolated and identified. Most of isolates belonged to Actinobacteria and Firmicutes division and only a small number of isolates belonged to Proteobacteria. On the contrary, in arsenicfree soils and in an estuary with negligible level of arsenic, Jackson et al. (2005a,b) found that the majority of isolates were Proteobacteria, while only few isolates belonged to Actinobacteria and Firmicutes. The less contaminated Dhal soil showed more diverse bacterial population which belonged to at least nine genera, in accordance with the results of Jackson et al. (2005a). Our results together with those of Jackson et al. (2005a,b) and Achour et al. (2007) confirm the wide distribution of phylogenetically diverse arsenic-resistant bacteria in the environment. The isolate Dhal Rw showed 97\% 16S rDNA sequence homology with O. doudoroffii (Brown et al. 2001). None of three Oceanimonas species recognized up to now have been characterized in terms of arsenic resistance. All other isolates belonged to species reported to have arsenic resistance or to be involved in arsenic cycling in soils and waters (Anderson and Cook 2004; Macur et al. 2004; Achour et al. 2007). Isolates Dhal G and Dhal S showed high $16 \mathrm{~S}$ rDNA sequence homology with Arsenicicoccus bolidensis, a new genus recently proposed (Collins et al. 2004). The type strain A. bolidensis has been isolated from sediments containing mine waste in Sweden and has been reported to posses both $\mathrm{As}(\mathrm{V})$ reduction mechanisms that impart resistance to $\mathrm{As}(\mathrm{V})$ toxicity or coupled to respiration of $\mathrm{As}(\mathrm{V})$ (Routh et al. 2007). Differently from the A. bolidensis type strain, Dhal $\mathrm{G}$ and Dhal $\mathrm{S}$ did not respire $\mathrm{As}(\mathrm{V})$ under anaerobic conditions.

Although arsenic content of the two soils was moderate, many isolates were highly resistant to both forms of arsenic indicating that the level of bacterial arsenic resistance can be many folds higher than the arsenic content of the soil, in accordance with other similar studies (Jackson et al. 2005a; Achour et al. 2007). Three Arthrobacter spp. from Dhal soil, although showing identical $16 \mathrm{~S}$
rRNA gene sequences based on ARDRA profile, differed in their arsenic resistance (Table 2) thus confirming that variation in the resistance can occur within same species. High arsenic resistance in some isolates may be due to presence of multiple sets of ars operon present on chromosome (Ordóñez et al. 2005) or transposon (Tuffin et al. 2006).

Although molecular determinant sequences for arsenic resistance are known for many bacteria, we found such sequences in three isolates from Dhal soil and in one Bacillus sp. from Rice soil (Fig. 3). The absence of arsenic resistance genes in most of the isolates may be inferred to sequences sufficiently different from the primers used in this study and to the diversity of arsenic resistance genes (Jackson and Dugas 2003; Achour et al. 2007). Relatedness of amino acid sequence of the ArsB protein of A. agilis Dhal Rr with Arthrobacter sp. A01 and not with other known ArsB proteins was in agreement with the results of Achour et al. (2007). Moreover, a larger arsB gene fragment $(850 \mathrm{bp}$ ) than the expected one of $750 \mathrm{bp}$ was amplified from both, Dhal Rr and A01 strains, thus indicating the probable existence of a new subgroup of ArsB proteins among bacteria. A gene fragment of putative arsenite efflux pump (ACR 3(2)) was amplified from isolate Dhal $\mathrm{Rw}$ which was unable to reduce arsenate, suggesting that the mechanism of arsenate resistance in this bacterium relies on prevention of $\mathrm{As}(\mathrm{V})$ uptake, rather than an intracellular arsenate reduction to arsenite followed by rapid export. An alternative mechanism than reduction to As(III) and efflux can not however be excluded for this strain. Such an alternative mechanism has been proposed by Baker-Austin et al. (2007) for the archaeon Ferroplasma acidarmanus F1 that, although highly resistant to both $\mathrm{As}(\mathrm{V})$ and $\mathrm{As}(\mathrm{III})$, is unable to reduce $\mathrm{As}(\mathrm{V})$.

Twenty bacteria isolated from the arsenic-enrichment cultures were capable of reducing $\mathrm{As}(\mathrm{V})$ but not of oxidizing As(III), probably due to the absence of genetic determinants coding for the arsenite oxidase genes (Mukhopadhyay et al. 2002). The mechanism of As(V) reduction by isolates can be related to a detoxification purpose as in aerobic conditions the arsenate reductase, which is encoded by ars $C$ gene, is involved in $\mathrm{As}(\mathrm{V})$ reduction. Further, the amplification of $\operatorname{ars} B, A C R 3 p$ and ars $C$ genes in some isolates confirmed the presence of detoxification mechanism for the reduction of $\mathrm{As}(\mathrm{V})$. None of the As(V)-reducing isolates could grow under the conditions tested here for dissimilatory $\mathrm{As}(\mathrm{V})$ reduction, where lactate served as the primary carbon and energy source and $\mathrm{As}(\mathrm{V})$ as terminal electron acceptor. This behaviour is not surprising considering that the isolates were enriched under aerobic conditions. However, the detoxification pathway can occur either aerobically or 
anaerobically and is not necessarily governed by prevailing redox conditions (Jackson et al. 2001).

The results obtained in this study give evidence of the presence of phylogenetically diverse arsenic-resistant bacteria in agricultural soils and that the resistance levels of these bacteria are regardless of the arsenic contamination. Although direct role of these bacteria in arsenic mobilization was not studied, the ability of the isolates to reduce $\mathrm{As}(\mathrm{V})$ suggests that these bacteria can potentially mediate arsenic transformations in these soils and their role in the arsenic cycling in these soils may become relevant with changing environmental conditions.

\section{Acknowledgements}

The research was supported by Programma di Interesse Nazionale (PRIN) 2004 project of Italian Ministry for University and Research. S.P.B. is the recipient of a 'Research Doctorate in Technological Innovations for Food and Environmental Sciences' research fellowship of Milan University. The authors wish to thank Dr M. Martin, Department of Valorisation and Protection of Agro Forest Resources (University of Torino, Italy), for providing soils and their chemical characterization.

\section{References}

Abedin, M.J., Feldmann, J. and Meharg, A.A. (2002) Uptake kinetics of arsenic species in rice plants. Plant Physiol 128, 1120-1128.

Achour, A.R., Bauda, P. and Billard, P. (2007) Diversity of arsenite transporter genes from arsenic-resistant soil bacteria. Res Microbiol 158, 128-137.

Alam, M.B. and Sattar, M.A. (2000) Assessment of arsenic contamination in soils and waters in some areas of Bangladesh. Water Sci Tech 42, 185-193.

Anderson, C.R. and Cook, G.M. (2004) Isolation and characterization of arsenate-reducing bacteria from arseniccontaminated sites in New Zealand. Curr Microbiol 48, 341-347.

Baker-Austin, C., Dopson, M., Wexler, M., Sawers, R.G., Stemmler, A., Rosen, B.P. and Bond, P. (2007) Extreme arsenic resistance by the acidophilic archaeon 'Ferroplasma acidarmanus' Fer1. Extremophiles 11, 425-434.

Bissen, M. and Frimmel, F.H. (2003) Arsenic, a review. Part I: occurrence, toxicity, speciation, mobility. Acta Hydrochim Hydrobiol 31, 9-18.

Brown, G.R., Sutcliffe, I.C. and Cummings, S.P. (2001) Reclassification of [Pseudomonas] doudoroffii (Baumann et al. 1983 ) into the genus Oceanomonas gen. nov. as Oceanomonas doudoroffii comb. nov., and description of a phenol-degrading bacterium from estuarine water as Oceanomonas baumannii sp. nov. Int J Syst Evol Microbiol 51, 67-72.
Cavalca, L., Dell'Amico, E. and Andreoni, V. (2004) Intrinsic bioremediability of an aromatic hydrocarbon-polluted groundwater: diversity of bacterial population and toluene monoxygenase genes. Appl Microbiol Biotech 64, 576-587.

Cervantes, C. and Chavez, J. (1992) Plasmid-determined resistance to arsenic and antimony in Pseudomonas aeruginosa. A van Leeuw 61, 333-337.

Cervantes, C., Ji, G., Ramı'rez, J.L. and Silver, S. (1994) Resistance to arsenic compounds in microorganisms. FEMS Microbiol Rev 15, 355-367.

Chowdhury, A.M.R. (2004) Arsenic crisis in Bangladesh. Sci Am 291, 87-91.

Collins, M.D., Routh, J., Saraswathy, A., Lawson, P.A., Schumann, P., Welinder-Olsson, C. and Falsen, E. (2004) Arsenicicoccus bolidensis gen. nov., sp. nov., a novel actinomycete isolated from contaminated lake sediment. Int $J$ Syst Evol Microbiol 54, 605-608.

Cullen, W.R. and Reimer, K.J. (1989) Arsenic speciation in the environment. Chem Rev 89, 713-764.

Cummings, D.E., Caccavo, F., Fendorf, S. and Rosenzweig, R.F. (1999) Arsenic mobilization by the dissimilatory $\mathrm{Fe}(\mathrm{III})$-reducing bacterium Shewanella alga BrY. Environ Sci Technol 33, 723-729.

Huq, I., Rahman, A.S.M., Sultana, S. and Naidu, R. (2003). Extent and severity of arsenic contamination in soils of Bangladesh. in Fate of Arsenic in the Environment ed. Ahmed, M.F. and Ali, Z.A. pp. 69-84. Dhaka, Bangladesh: BUET-UNU International Symposium.

Islam, F.S., Gault, A.G., Boothman, C., Polya, D.A., Charnock, J.M., Chatterjee, D. and Lloyd, J.R. (2004) Role of metalreducing bacteria in arsenic release from Bengal delta sediments. Nature 430, 68-71.

Jackson, C.R. and Dugas, S.L. (2003) Phylogenetic analysis of bacterial and archaeal ars $\mathrm{C}$ gene sequences suggests an ancient, common origin for arsenate reductase. BMC Evol Biol 3, 18.

Jackson, C.R., Langner, H.W., Donahoe-Christiansen, J., Inskeep, W.P. and McDermott, T.R. (2001) Molecular analysis of microbial community structure in an arseniteoxidizing acidic thermal spring. Environ Microbiol 3, 532542.

Jackson, C.R., Dugas, S.L. and Harrison, K.G. (2005a) Enumeration and characterization of arsenate-resistant bacteria in arsenic free soils. Soil Biol Biochem 37, 2319-2322.

Jackson, C.R., Harrison, K.G. and Dugas, S.L. (2005b) Enumeration and characterization of culturable arsenate resistant bacteria in a large estuary. Syst Appl Microbiol 28, 727-734.

Jensen, V. (1962) Studies on the microflora of Danish beech forest soils. I. The dilution plate count technique for the enumeration of bacteria and fungi in soil. Zentralbl. Bakteriol., II Abt. 116, 13-32.

Kumar, S., Tamura, K. and Nei, M. (2004) MEGA3: integrated software for molecular evolutionary genetics analysis and sequence alignment. Brief Bioinform 5, 150-163. 
Kunito, T., Senoo, K., Saeki, K., Oyaizu, H. and Matsumoto, S. (1999) Usefulness of the sensitivity-resistance index to estimate the toxicity of copper on bacteria in coppercontaminated soils. Ecotox Environ Safe 44, 182-189.

Lin, Y-F, Walmsley, A.R. and Rosen, B.P. (2006) An arsenic metallo-chaperone for an arsenic detoxification pump. Proc Natl Acad Sci USA 103, 15617-15622.

Macur, R.E., Wheeler, J.T., McDermott, T.R. and Inskeep, W.P. (2001) Microbial populations associated with the reduction and enhanced mobilization of arsenic in mine tailings. Environ Sci Technol 35, 3676-3682.

Macur, R.E., Jackson, C.R., Botero, L.M., Mcdermott, T.R. and Inskeep, W.P. (2004) Bacterial populations associated with the oxidation and reduction of arsenic in an unsaturated soil. Environ Sci Technol 38, 104-111.

Martin, M., Violante, A. and Barberis, E. (2007) Fate of arsenite and arsenate in flooded and not flooded soils of southwest Bangladesh irrigated with arsenic contaminated water. J Environ Sci Heal A 42, 1775-1783.

Mehrag, A.A. and Rahman, M.M. (2003) Arsenic contamination of Bangladesh paddy field soils: implications for rice contribution to arsenic consumption. Environ Sci Technol 37, 229-234.

Mergeay, M., Nies, D., Schlegel, H.G., Gerits, J., Charles, P. and Gijsegem, F.V. (1985) Alcaligenes eutrophus CH34 is a facultative chemolithotroph with plasmid-bound resistance to heavy metals. J Bacteriol 162, 328-334.

Monod, J. (1950) The technique of continuous cultures theory and application. Ann Inst Pasteur 79, 390-410.

Mukhopadhyay, R. and Rosen, B.P. (2002) Arsenate reductases in prokaryotes and eukaryotes. Environ Health Perspect 110, 745-748.

Mukhopadhyay, R., Rosen, B.P., Phung, L.T. and Silver, S. (2002) Microbial arsenic: from geocycles to genes and enzymes. FEMS Microbiol Rev 26, 311-325.

Neff, J.M. (1997) Ecotoxicology of arsenic in marine environment. Environ Toxicol Chem 16, 917-927.

Ordóñez, E., Letek, M., Valbuena, N., Gil, J.A. and Mateos, L.M. (2005) Analysis of genes involved in arsenic resistance in Corynebacterium glutamicum ATCC 13032. Appl Environ Microbiol 71, 6206-6215.

Oremland, R.S. and Stolz, J.F. (2003) The ecology of arsenic. Science 300, 939-944.
Oremland, R.S., Kulp, T.R., Switzer Blum, J., Hoeft, S.E., Baesman, S., Miller, L.G. and Stolz, J.F. (2005) A microbial arsenic cycle in a salt saturated, extreme environment. Science 308, 1305-1308.

Pochon, J. and Tardieux, P. (1962) Techniques d'Analyse en Microbiologie du Sol. France: Ėditions de la Tourelle, St-Mandé.

Rosen, B.P. (2002) Biochemistry of arsenic detoxification. FEBS Lett 529, 86-92.

Routh, J., Saraswathy, A. and Collins, M.D. (2007) Arsenicicoccus bolidensis a novel arsenic reducing actinomycete in contaminated sediments near the Adak mine (northern Sweden): impact on water chemistry. Sci Total Environ 379, 216-225.

Sadiq, M. (1997) Arsenic chemistry in soils: an overview of thermodynamic predictions and field observations. Water Air Soil Pollut 93, 117-136.

Silver, S. and Phung, L.T. (2005) A bacterial view of the periodic table: genes and proteins for toxic inorganic ions. J Ind Microbiol Biotechnol 32, 587-605.

Smedley, P.L. and Kinniburgh, D.G. (2002) A review of the source, behaviour and distribution of arsenic in natural waters. Appl Geochem 17, 517-568.

Stolz, J., Basu, P. and Oremland, R. (2002) Microbial transformation of elements: the case of arsenic and selenium. Int Microbiol 5, 201-207.

Summers, A.O. and Silver, S. (1978) Microbial transformations of metals. Annu Rev Microbiol 32, 637-672.

Tuffin, I.M., Hector, S.B., Deane, S.M. and Rawlings, D.E. (2006) Resistance determinants of a highly arsenic-resistant strain of Leptospirillum ferriphilum isolated from a commercial biooxidation tank. Appl Environ Microbiol 72, 2247-2253.

Weisburg, W.G., Barns, S.M., Pelletier, D.A. and Lane, D. J. (1991) 16S ribosomal DNA amplification for phylogenetic study. J Bacteriol 173, 697-703.

Wenzel, W.W., Kirchbaumer, N., Proshanka, T., Stingeder, G., Lombi, E. and Adriano, D.C. (2001) Arsenic fractionation in soils using an improved sequential extraction procedure. Anal Chim Acta 436, 309-323.

Wysocki, R., Chery, C.C., Wawrzycka, D., Van Hulle, M., Cornelis, R., Thevelein, J.M. and Tamàs, M.T. (2001) The glycerol channel Fps1p mediates the uptake of arsenite and antimonite in Saccharomyces cerevisiae. Mol Microbiol 40, 1391-1401. 